\title{
Zastosowanie testów toksykologicznych w przemyśle naftowym
}

\begin{abstract}
Obecność różnorodnych zanieczyszczeń w odpadach przemysłowych oraz możliwość zanieczyszczenia wód powierzchniowych i podziemnych oraz gleby substancjami toksycznymi, które nie są wymieniane w obowiązujących wykazach środków toksycznych, stwarza konieczność przeprowadzania badań własności toksycznych gleby, wód i odpadów z wykorzystaniem testów toksykologicznych bezpośredniego kontaktu.

Omówiono badania zmian toksyczności zachodzących podczas procesów bioremediacji zastarzałych odpadów wiertniczych z dołu urobkowego. Przedstawiono także wyniki badań toksyczności płynów do hydraulicznego szczelinowania i uzyskiwanych płynów pozabiegowych. Przeprowadzone próby zastosowania nowoczesnych testów toksykologicznych (Microtox, MARA, test Amesa, testy typu toxkit) w przemyśle naftowym dowodzą, że uzyskane wyniki mogą stanowić podstawę do oceny zagrożeń stwarzanych dla środowiska oraz być pomocne przy wyborze metod zapobiegania skażeniom oraz zagospodarowania różnorodnych materiałów i odpadów generowanych przez przemysł.
\end{abstract}

Słowa kluczowe: testy toksyczności, bioremediacja, odpady wiertnicze, doły urobkowe, płyny szczelinujące, ciecze pozabiegowe.

\section{Application of toxicological tests in oil industry}

The presence of various pollutants in industrial waste and the possibility of surface and underground waters, and soil contamination with unknown substances (not listed as toxic substances) creates the necessity to examine soil, water and waste toxic properties with the use of toxicological tests of direct contact.

Described are studies of soil toxicity changes during bioremediation of old drilling wastes. The data of toxicity tests of hydraulic fracturing fluids and flowback waters is also presented. Practical application of innovative toxicological tests (Microtox, MARA, AMES, and toxkit-type tests) carried out in the oil industry, have proven, that the data can be used to assess the environmental threat. They can also be helpful in the selection of methods for preventing contamination and management of different materials and waste generated by oil industry.

Key words: toxicological tests, bioremediation, drill wastes, waste pit, fracturing fluids, flowback waters.

\section{Wprowadzenie}

Analiza bioindykacyjna jest częścią rozległej wiedzy określanej mianem ekotoksykologii. Współczesna ekotoksykologia jest interdyscyplinarną, intensywnie rozwijającą się gałęzią nauki obejmującą: chemię, ekologię i toksykologię, której cel stanowi między innymi ocena stanu środowiska i pośrednio ochrona zdrowia człowieka.

W chwili obecnej coraz szerzej stosowane są testy toksykologiczne wykorzystujące organizmy żywe przechowywane w stadium uśpienia lub unieruchomienia (formy kryptobiotyczne), które mogą być prawie natychmiast wykorzystane do przeprowadzenia badań. Żywy organizm jest swoistym odczynnikiem, wewnątrz którego zachodzą procesy biochemiczne, a ich zaburzenie (np. przez obecność zanieczyszczeń) skutkuje zmianami morfologicznymi ciała, chorobami, a w końcu śmiercią, dostarczając istotnych informacji o stanie ekosystemu $[4,8,9]$.

Testy toksykologiczne bezpośredniego kontaktu pozwalają na jednoczesne określenie szkodliwego działania wszystkich substancji znajdujących się w badanej próbce na wybrane organizmy żywe, z uwzględnieniem interakcji zachodzących pomiędzy wszystkimi elementami badanego układu [1]. Mikrobiotesty typu toxkit zapewniają łatwość stosowania 
oraz odpowiednią czułość i powtarzalność wykonywanych badań $[2,3,5,8,11]$. Użycie baterii bioindykatorów należących do różnych grup taksonomicznych: bakterii, pierwotniaków, skorupiaków, glonów i roślin wyższych oraz reprezentujących wszystkie poziomy troficzne: producentów, konsumentów i reducentów umożliwia kompleksową ocenę stanu badanego środowiska [11]. Przed wprowadzeniem do stosowania nowego typu mikrobiologicznych testów toksyczności przeprowadzono szeroko zakrojone badania, które pozwoliły na sprawdzenie możliwości wykorzystania i powtarzalności wyników testów w różnorodnych układach pomiarowych i w różnych laboratoriach, a także posłużyły do opracowania prostego systemu oceny toksyczności pozwalającego na klasyfikację badanych próbek [10].
W INiG - PIB od kilku lat trwają prace wdrożeniowe nad zastosowaniem testów toksykologicznych nowej generacji do określania rzeczywistej toksyczności odpadów (w tym zanieczyszczeń ropopochodnych), wód złożowych oraz płynów pozabiegowych z przemysłu wydobywczego nafty i gazu. Wyniki dotychczasowych badań potwierdzają zasadność stosowania testów toksykologicznych podczas oceny zagrożeń stwarzanych przez wody złożowe i inne odpady dla środowiska $[6,7$, 12-14]. Testy te pozwalają ponadto na określenie zmian toksyczności podczas prowadzenia procesów oczyszczania gleby oraz wody. Są także pomocne przy ustalaniu działań, które należy podjąć w przypadku przedostania się do wody i gleby odpadów lub innych substancji wykorzystywanych w przemyśle naftowym, minimalizując stwarzane zagrożenia.

\section{Ocena toksykologiczna odpadu z dołu urobkowego G-70 w trakcie procesu bioremediacji}

Dół urobkowy G-70 (z uszczelnieniem iłowym) wykonany został w celu zgromadzenia odpadów zanieczyszczonych substancjami ropopochodnymi i zużytej płuczki wiertniczej, wytworzonych podczas udarowego wiercenia otworu G-70. Uszkodzone obwałowanie oraz brak zabezpieczeń powodowały z jednej strony wymywanie zanieczyszczeń do otaczającego środowiska, a z drugiej - zagrożenie dla ludzi i zwierząt wywoływane przez niską wytrzymałość mechaniczną zgromadzonych odpadów (konsystencja szlamu z naniesioną na powierzchnię cienką warstwą ziemi i materiału roślinnego).

Produkty ropopochodne (główne zanieczyszczenia) stanowią złożoną mieszaninę związków o zróżnicowanych własnościach biologicznych, które mogą być przyczyną niekorzystnych dla człowieka i organizmów żywych zmian zachodzących w skażonym środowisku. W wyniku prowadzonych prac bioremediacyjnych (obejmujących bioremediację podstawową stymulowaną poprzez dozowanie substancji biogennych oraz inokulację biopreparatami na bazie bakterii autochtonicznych, grzybów i drożdży) zachodzą procesy biodegradacji zanieczyszczeń ropopochodnych. Prowadzi to do obniżenia zawartości węglowodorów ropopochodnych (głównego toksykantu) i obniżenia toksyczności gleby.

Ocenę skuteczności zabiegów bioremediacyjnych na terenie dołu urobkowego G-70 rozszerzono o monitoring toksykologiczny, który przeprowadzono przy użyciu żywych organizmów reprezentujących wszystkie poziomy troficzne: producentów (test Phytotoxkit), konsumentów (test Ostracodtoxkit) i reducentów (test Microtox SPT), oraz o test oceny ryzyka środowiskowego (MARA), a dodatkowo wykonano badania obecności czynników mutagennych (test Amesa). Pozwala to na kompleksową ocenę stanu badanego środowiska glebowego. Materiałem badawczym były próbki pobrane z interwału 0-50 cm p.p.t. z obszaru dołu urobkowego G-70 $\mathrm{w}$ trakcie prowadzenia procesu oczyszczania.

Test Microtox SPT (ze względu na krótki czas wykonania) posłużył do prowadzenia szczegółowego monitoringu zmian toksyczności odpadu podczas procesu bioremediacji (rysunek 1). Sukcesywne obniżanie zawartości zanieczyszczeń ropopochodnych powodowało ogólnie obniżanie toksyczności badanego odpadu z poziomu TU $=36,7$ (po remediacji wstępnej) do braku toksycznych oddziaływań po zakończeniu oczyszczania.

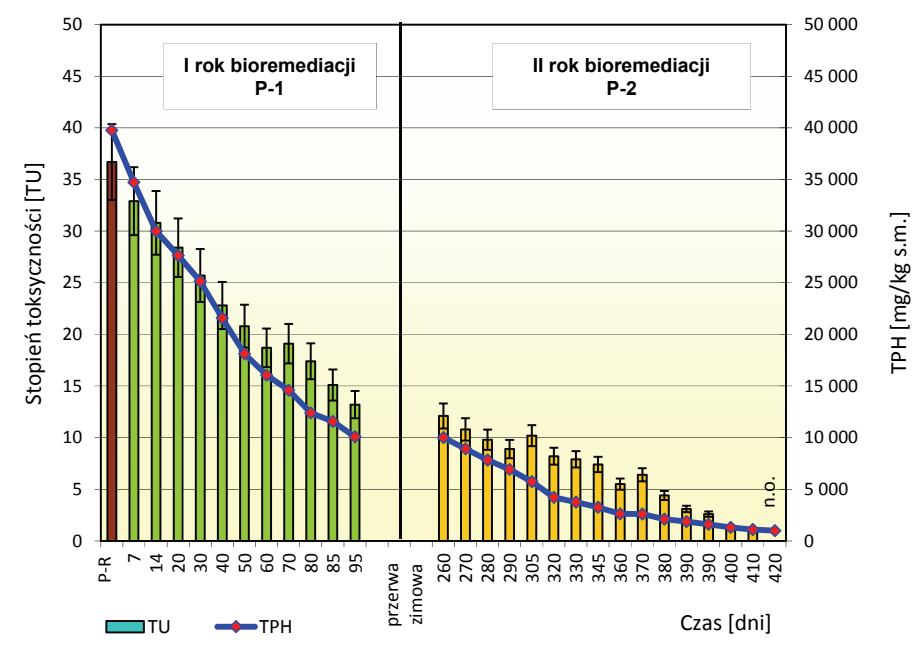

Rys. 1. Wpływ zanieczyszczeń ropopochodnych na stopień toksyczności (TU) gleby podczas bioremediacji metodą in situ terenu dołu urobkowego G-70 (test Microtox SPT, liczba powtórzeń $n=6$ )

Testy typu toxkit wykorzystywano do kontroli procesu bioremediacji w kluczowych punktach: PS - próbka surowa, $\mathbf{P}-\mathbf{R}$ - po remediacji wstępnej, P-1 - po inokulacji biopreparatem GR-70-1, P-2 - po inokulacji biopreparatem GR-70-2 (zakończenie procesu oczyszczania). 
Przeprowadzone testy toksyczności typu toxkit (Phytotoxkit i Ostracodtoxkit) wykazały, że surowe próbki gleby z dołu urobkowego G-70 przed procesem oczyszczania cechują się znaczną toksycznością w stosunku do zastosowanych organizmów testowych (rysunki 2 i 3). Zanieczyszczenia zawarte w próbkach badanej gleby wywoływały efekt testowy na poziomie od $52 \%$ do $74 \%$.
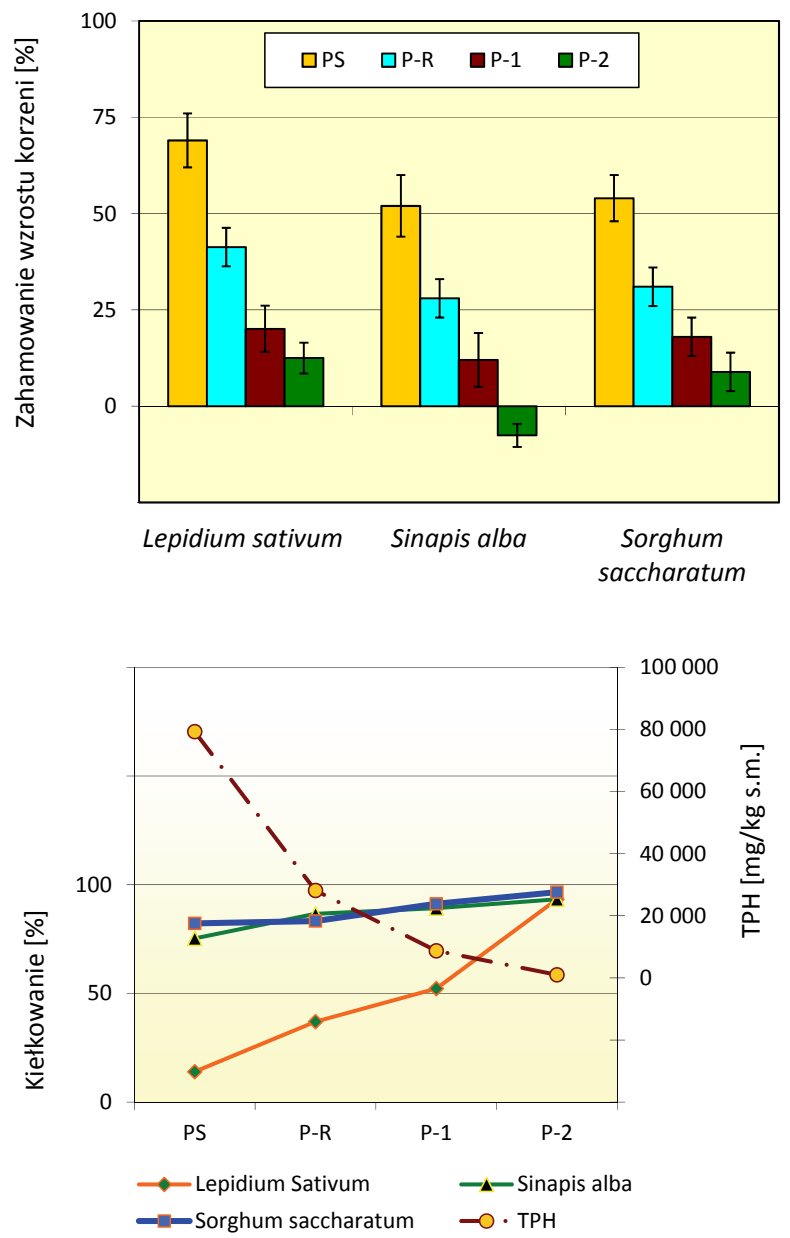

Rys. 2. Kiełkowanie oraz zahamowanie wzrostu korzeni w teście Phytotoxkit - odpad z dołu urobkowego G-70 $\mathrm{w}$ trakcie bioremediacji metodą in situ $(n=3, p<0,05)$

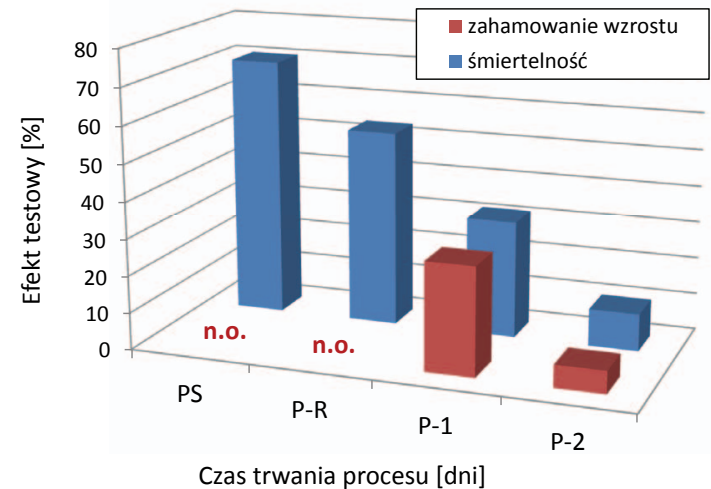

Rys. 3. Śmiertelność i zahamowanie wzrostu Heterocypris incongruens (test Ostracodtoxkit) w odpadzie z dołu urobkowego

G-70 podczas bioremediacji metodą in situ $(n=6, p<0,05)$
W analizowanych kolejnych etapach oczyszczania toksyczność badanych próbek malała sukcesywnie wraz z obniżeniem zawartości węglowodorów. Testy przeprowadzone po zakończeniu oczyszczania wskazują na brak toksyczności gleby.

Test oceny ryzyka środowiskowego (MARA) oparty na reakcji 10 szczepów bakterii i 1 szczepu drożdży - reprezentantów różnych grup taksonomicznych pozwala na jednoczesną ocenę toksycznego oddziaływania badanej próbki na organizmy o bardzo zróżnicowanej charakterystyce. Podobnie jak w testach typu toxkit toksyczność (MTC - microbial toxic concentration) odpadu surowego kształtowała się na podwyższonym poziomie (MTC od $2,9 \%$ do $9,1 \%, \mathrm{MTC}_{\mathrm{sr}}=5,11 \%$ ), natomiast gleba z dołu urobkowego G-70 po procesach oczyszczania była nietoksyczna (MTC od $38 \%$ do $91 \%, \mathrm{MTC}_{\mathrm{sr}}=68 \%$ ) (rysunek 4).
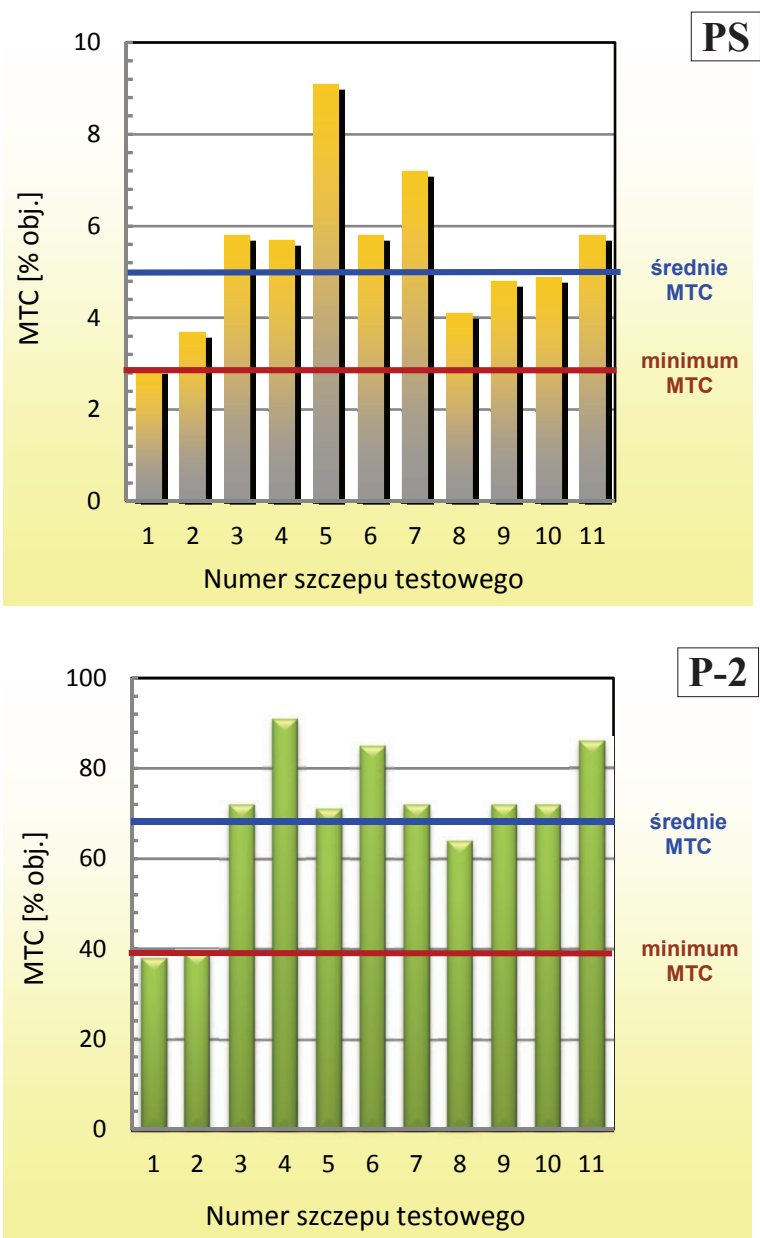

Rys. 4. Wyniki testu oceny ryzyka środowiskowego (MARA) uzyskane dla odpadu surowego (PS) i po zakończeniu bioremediacji (P-2) z dołu urobkowego G-70

Wykonano także mikropłytkowy test mutagenności Amesa, określający występowanie czynników mutagennych i rakotwórczych, których obecność wykazywana jest jako liczba indukowanych rewertantów na podłożu bez histydyny. Przeprowadzone testy dowiodły, że odpad surowy zawierający 
wysokie stężenia węglowodorów (119 $228 \mathrm{mg} / \mathrm{kg}$ s.m.) posiada własności mutagenne (zwiększenie liczby mutacji szczepu TA-100). Wskaźnik mutagenności (stosunek liczby rewertantów indukowanych do spontanicznych) dla odpadu surowego z dołu urobkowego G-70 wynosił 8,06 .

$\mathrm{W}$ trakcie prowadzenia procesów oczyszczania zauważono stopniowe obniżanie się właściwości mutagennych gleby, natomiast próbki gleby i ziemi z dołu urobkowego G-70 po zakończeniu procesu bioremediacji nie wykazywały własności mutagennych i rakotwórczych.

Dla powyższych próbek liczba rewertantów indukowanych bez histydyny była nieznacznie wyższa (mniej niż dwukrot-
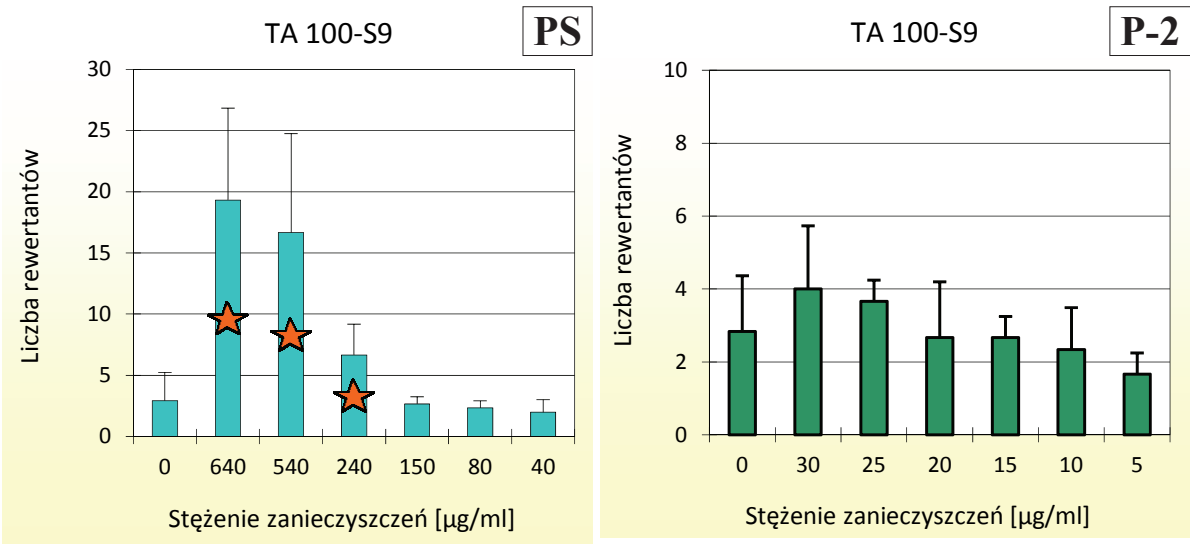

Rys. 5. Wpływ zanieczyszczeń ropopochodnych na liczbę rewertantów indukowanych w odpadzie surowym (PS) i po zakończeniu bioremediacji (P-2) metodą in situ

nie) od liczby mutantów spontanicznych na podłożu kontrolnym - wskaźnik mutagenności na poziomie 0,29-0,54.

\section{Badania toksyczności płynów zabiegowych i cieczy pozabiegowych}

W przemyśle naftowym często stosowane są różnorodne płyny zabiegowe służące do intensyfikacji wydobycia. Płyny te często sporządzane są z wykorzystaniem bardzo toksycznych substancji chemicznych. Także płyny odbierane po przeprowadzonych zabiegach mogą charakteryzować się wysokimi toksycznościami i kontakt zarówno płynów zabiegowych, jak i pozabiegowych z elementami środowiska może negatywnie wpływać na organizmy żywe. W celu przeprowadzenia oceny zagrożeń stwarzanych podczas zabiegów intensyfikacyjnych proponuje się zastosowanie testów toksykologicznych bezpośredniego kontaktu, których wyniki dobrze uzupełniają informacje uzyskiwane dzięki wykonaniu standardowych analiz fizykochemicznych i chromatograficznych. Badania z użyciem testów toksykologicznych przedstawiono na przykładzie zabiegu hydraulicznego szczelinowania.

W celu oceny płynu szczelinującego w aspekcie ekologicznym badaniom poddano próbki dwóch płynów szczelinujących sporządzonych laboratoryjnie oraz jednego zastosowanego $\mathrm{w}$ zabiegu hydraulicznego szczelinowania odwiertu badawczego W-2. Analiza fizykochemiczna płynu szczelinującego (próbka 1) sporządzonego na bazie polimeru hydroksypropyloguar (HPG) wykazała, że zawiera on śladowe ilości substancji szkodliwych dla środowiska oraz podwyższone zawartości substancji organicznych $\left(\mathrm{ChZT}_{\mathrm{Cr}}=16470 \mathrm{mg} \mathrm{O} / \mathrm{dm}^{3}\right)$ - głównie polimeru HPG. Natomiast płyn szczelinujący sporządzony laboratoryjnie na bazie poliakryloamidu (próbka 2) cechuje się znacznie niższym zapotrzebowaniem na tlen $\left(\mathrm{ChZT}_{\mathrm{Cr}}=1945 \mathrm{mg} \mathrm{O}_{2} / \mathrm{dm}^{3}\right)$ przy podobnie niskiej zawartości pozostałych składników szkodliwych.

Do przeprowadzenia zabiegu hydraulicznego szczelinowania na odwiercie W-2 wykorzystano płyn typu slickwater. Płyn (próbka 3) ten charakteryzował się podwyższonym wskaźnikiem zapotrzebowania na tlen $\left(\mathrm{ChZT}_{\mathrm{Cr}}=7958 \mathrm{mg} \mathrm{O} / \mathrm{dm}^{3}\right)$. Zawartości pozostałych substancji szkodliwych, w tym TPH oraz metali ciężkich, odnotowano na niskim poziomie.

Analiza toksykologiczna próbek płynów szczelinujących z wykorzystaniem wytypowanych biotestów pozwoliła na stwierdzenie, że badane płyny są nietoksyczne. Na rysunku 6 przedstawiono przykładowo wyniki testów dla płynu szczelinującego zastosowanego na odwiercie W-2 (próbka 3).
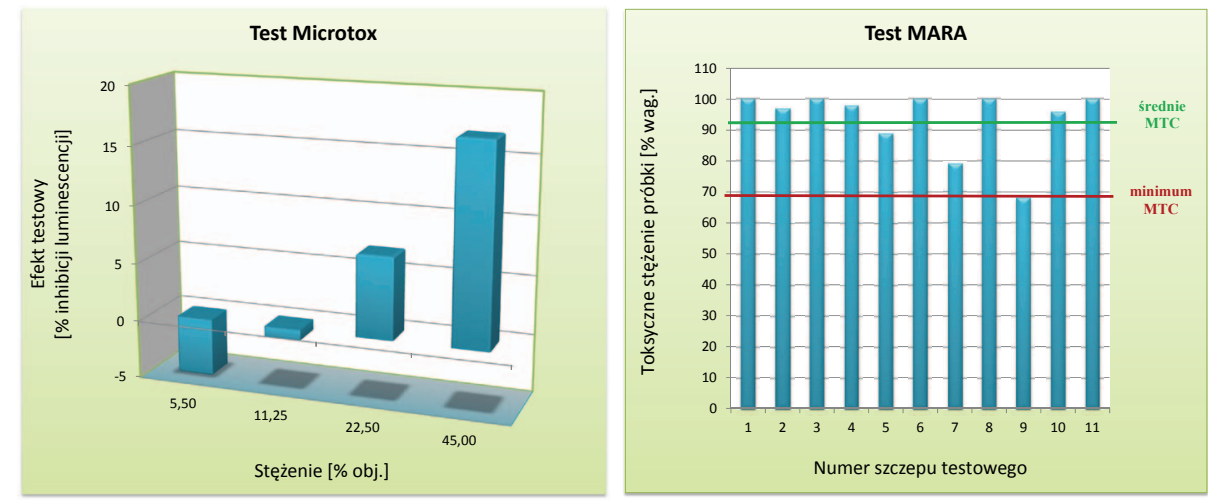

Rys. 6. Wyniki badań toksyczności ostrej (test Microtox i MARA) próbki płynu do hydraulicznego szczelinowania odwiertu W-2 (próbka 3)

Podczas prowadzenia procesu hydraulicznego szczelinowania mogą powstawać duże ilości płynnych odpadów poza- 
biegowych (ang. flowback water) usuwanych w trakcie wywołania otworu. Podczas kontaktu ze skałami oraz wodą złożową skład chemiczny płynu szczelinującego ulega zmianie. Próbki płynu pozabiegowego charakteryzują się wysokim zasoleniem oraz mogą zawierać: rozpuszczone substancje stałe (TDS), składniki organiczne (węglowodory alifatyczne i aromatyczne), metale ciężkie i inne występujące w złożu substancje.

Analiza chemiczna próbek cieczy pozabiegowej po hydraulicznym szczelinowaniu odwiertu W-2 wskazuje, że zawartość substancji rozpuszczonych wzrasta wraz ze wzrostem objętości wydobytej cieczy pozabiegowej, w szczególności chlorków (34 567-83 $662 \mathrm{mg} / \mathrm{dm}^{3}$ ), kationów sodu (23 758-30 344 $\left.\mathrm{mg} / \mathrm{dm}^{3}\right)$, wapnia $\left(4669-6621 \mathrm{mg} / \mathrm{dm}^{3}\right)$ i magnezu $(1270-1984$ $\mathrm{mg} / \mathrm{dm}^{3}$ ). Stwierdzono także wzrost zapotrzebowania na tlen $\left(\mathrm{ChZT}_{\mathrm{Cr}}\right)$ z $5641 \mathrm{mg} \mathrm{O} / \mathrm{dm}^{3}$ do $18541 \mathrm{mg} \mathrm{O} / \mathrm{dm}^{3}$ oraz TPH z $8,4 \mathrm{mg} / \mathrm{dm}^{3}$ do $184 \mathrm{mg} / \mathrm{dm}^{3}$. Zawartość metali ciężkich odnotowano na niskim poziomie.

Przeprowadzona analiza z wykorzystaniem baterii testów toksykologicznych wykazała, że wraz ze wzrostem mineralizacji i zawartości zanieczyszczeń wzrastały właściwości toksyczne wydobytych cieczy pozabiegowych. Wszystkie analizowane próbki cieczy pozabiegowej wykazują istotny efekt toksyczny i należy je zakwalifikować do II-III klasy toksyczności. Najwyższy efekt toksyczny odnotowano dla skorupiaków w teście Daphtoxkit 48 h (TU w zakresie od 7,2 do 18,5) oraz najczulszym teście oceny ryzyka środowiskowego MARA (TU w zakresie od 5,9 do 17,2) - rysunek 7.

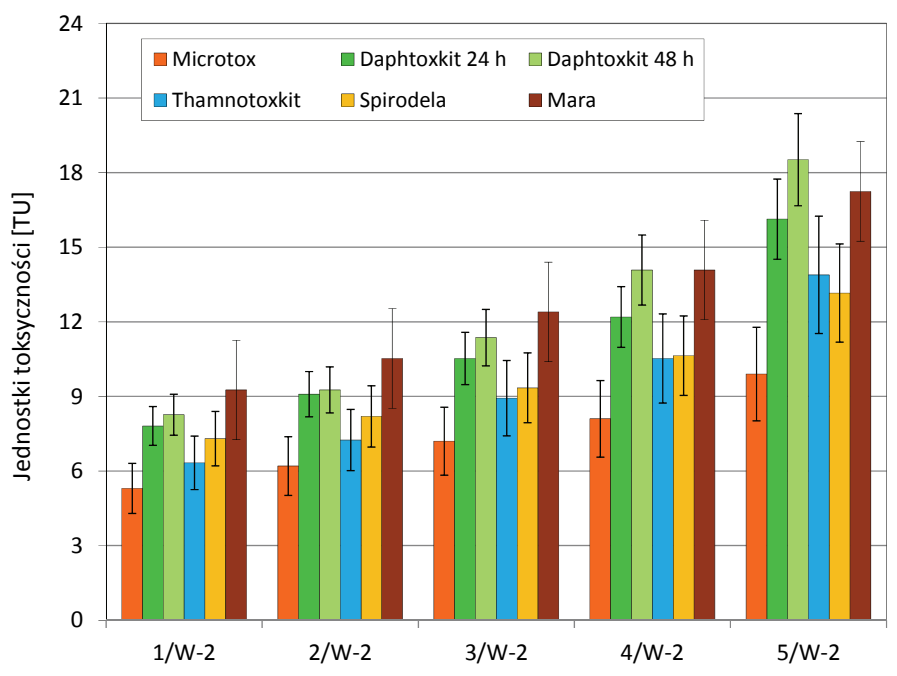

Rys.7. Porównanie wyników testów toksykologicznych wykonanych dla próbek cieczy pozabiegowej po hydraulicznym szczelinowaniu odwiertu W-2

Dane uzyskane podczas badań toksykologicznych w połączeniu z wynikami analiz fizykochemicznych pozwalają na monitorowanie zagrożeń stwarzanych przez ciecze pozabiegowe po hydraulicznym szczelinowaniu oraz umożliwiają określenie zmian w ich składzie w trakcie wywoływania odwiertu. Ponadto są pomocne przy ustalaniu kierunków zagospodarowania cieczy pozabiegowej, w tym także możliwości wykorzystania jako składnika do sporządzania kolejnych partii płynów szczelinujących.

\section{Podsumowanie}

Przeprowadzone próby wykorzystania testów toksykologicznych do określenia toksyczności próbek stosowanych materiałów (płynów zabiegowych) i odpadów z przemysłu naftowego wyraźnie wskazują, że uzyskiwane dane mogą być bardzo pomocne nie tylko podczas badań poziomu skażenia gleby i wody, lecz także na etapie projektowania zabiegów intensyfikacyjnych do oceny zagrożeń stwarzanych dla środowiska przez stosowa- ne środki chemiczne. Wyniki testów pozwalają na ocenę efektywności procesów oczyszczania, umożliwiają dobór zamienników o niższych toksycznościach w stosunku stosowanych środków chemicznych, wspomagają podejmowanie decyzji o poziomie zabezpieczeń stosowanych podczas wykorzystania substancji chemicznych, sposobach zagospodarowania odpadów oraz o doborze metod likwidacji awaryjnych skażeń środowiska.

Prosimy cytować jako: Nafta-Gaz 2018, nr 9, s. 684-689, DOI: 10.18668/NG.2018.09.07

Artykuł nadesłano do Redakcji 4.07.2018 r. Zatwierdzono do druku 12.09.2018 r.

Artykuł został opracowany na podstawie referatu wygłoszonego na Międzynarodowej Konferencji Naukowo-Technicznej GEOPETROL 2018 pt.: Rozwój technik poszukiwania i eksploatacji złóż węglowodorów. Zakopane-Kościelisko, 17-20.09.2018 r.

\section{Literatura}

[1] Augulyte L., Kliaugaite D., Racys V., Jankunaite D., Zaliauskiene A., Andersson P.L., Bergqvist P.A.: Chemical and Ecotoxicological Assessment of Selected Biologically Activated Sorbents for Treating Wastewater Polluted with Petroleum Products with Special Emphasis on Polycyclic Aromatic Hydrocarbons. Water, Air, and Soil Pollution 2008, vol. 195, no. 1, s. 243-256.
[2] Baran A., Tarnowski M.: Phytotoxkit/Phytotestkit and Microtox as tools for toxicity assessment of sediments. Ecotoxicology and Environmental Safety 2013, vol. 98, s. 19-27.

[3] Baudo R., Foudoulakis M., Rapis G., Perdaen K., Lanneau W., Paxinou A.-C.M., Kouvdou S., Persoone G.: History and sensitivity comparison of the Spirodela polyrhiza microbiotest and Lemna toxicity tests. Knowledge and Management of 
Aquatic Ecosystems 2015, vol. 416, no. 23, DOI: 10.1051/ $\mathrm{kmae} / 2015019$.

[4] Blinova I., Niskanen J., Kajankari P., Kanarbik L., Käkinen A., Tenhu H., Penttinen O.P., Kahru A.: Toxicity of two types of silver nanoparticles to aquatic crustaceans Daphnia magna and Thamnocephalus platyurus. Environ. Sci. Pollut. Res. Int. 2013, vol. 20, no. 5, s. 3456-3463.

[5] Chial B., Persoone G.: Cyst-based toxicity tests XII. Development of a short-chronic sediment toxicity test with the ostracod crustacean Heterocypris incongruens: Selection of test parameters. Environ. Toxicol. 2002, vol. 17, no. 6, s. 520-527.

[6] Foucault Y., Durand M.J., Tack K., Schreck E., Geret F., Leveque T., Pradère P., Goix S., Dumat C.: Use of ecotoxicity test and ecoscores to improve the management of polluted soils: case of a secondary lead smelter plant. Journal of Hazardous Materials 2013, vol. 246-247, s. 291-299.

[7] Jakubowicz P., Steliga T., Kluk D.: Ocena zmian toksyczności ostrej wód złożowych z wykorzystaniem testów ekotoksykologicznych. Nafta-Gaz 2013, nr 5, s. 409-417.

[8] Mankiewicz-Boczek J., Nałęcz-Jawecki G., Drobniewska A., Kaza M., Sumorok B., Izydorczyk K., Zalewski M., Sawicki J.: Application of a microbiotests battery for complete toxicity assessment of rivers. Ecotoxicology and Environmental Safety 2008, vol. 71, no. 3, s. 830-836.

[9] Matejczyk M., Płaza G.A., Nałęcz-Jawecki G., Ulfig K.,

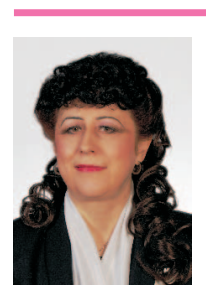

Prof. nzw. dr hab. inż. Teresa STELIGA

Kierownik Zakładu Technologii Eksploatacji

Płynów Złożowych.

Instytut Nafty i Gazu - Państwowy Instytut Badawczy

ul. Lubicz 25 A

31-503 Kraków

E-mail: teresa.steliga@inig.pl

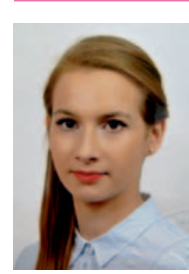

Mgr Katarzyna WOJTOWICZ

Specjalista inżynieryjno-techniczny w Zakładzie

Technologii Eksploatacji Płynów Złożowych

Instytut Nafty i Gazu - Państwowy Instytut Badawczy

ul. Lubicz $25 \mathrm{~A}$

31-503 Kraków

E-mail:katarzyna.wojtowicz@inig.pl
Markowska-Szczupak A.: Estimation of the environmental risk posed by landfills using chemical, microbiological and ecotoxicological testing of leachates. Chemosphere 2011, vol. 82, no. 7, s. 1017-1023.

[10] Persoone G.: Toxkit Microbiotests: Practical and Low Cost Tools for Research and Toxicity Monitoring. $3^{\text {rd }}$ International Symposium on Green Chemistry for Environment, Health and Development, 2012.

[11] Persoone G., Marsalek B., Blinova I., Torokne A., Zarina D., Manusadzianas L., Nałęcz-Jawecki G., Tofan L., Stepanova N., Tothova L., Kolar B.: A practical and user-friendly toxicity classification system with microbiotests for natural waters and wastewaters. Environ. Toxicol. 2003, vol. 18, no. 6, s. 393-397.

[12] Steliga T.: Ocena efektywności biodegradacji węglowodorów ropopochodnych $w$ zastarzałym odpadzie $z$ dołu urobkowego Graby-59 w warunkach przemystowych metoda in-situ. Nafta-Gaz 2014, nr 6, s. 351-364.

[13] Steliga T., Jakubowicz P., Kapusta P.: Changes in toxicity during treatment of wastewater from oil plant contaminated with petroleum hydrocarbons. Journal of Chemical Technology and Biotechnology 2015, vol. 90, no. 8, s. 1408-1418.

[14] Zima G.: Wykorzystanie metod bioindykacji do oceny toksyczności środków chemicznych stosowanych w składach płuczek wiertniczych. Nafta-Gaz 2012, nr 2, s. 115-122.

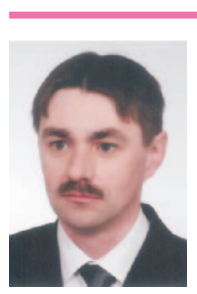

Mgr Piotr JAKUBOWICZ

Starszy specjalista badawczo-techniczny w Zakładzie Technologii Eksploatacji Płynów Złożowych. Instytut Nafty i Gazu - Państwowy Instytut Badawczy ul. Lubicz $25 \mathrm{~A}$

31-503 Kraków

E-mail: piotr.jakubowicz@inig.pl

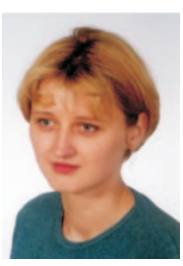

Mgr inż. Dorota KLUK

Starszy specjalista badawczo-techniczny w Zakładzie Technologii Eksploatacji Płynów Złożowych.

Instytut Nafty i Gazu - Państwowy Instytut Badawczy ul. Lubicz 25 A

31-503 Kraków

E-mail:dorota.kluk@inig.pl 